\title{
Pleural effusion in a patient with end-stage renal disease
}

Abeer Al Harby, ${ }^{*}$ Othman Al Furayh, ${ }^{*}$ Fouad Al Dayel, $\uparrow$ Abdullah Al Mobeireek *

$\mathrm{P}$ leural disease is a common problem in patients with chronic renal insufficiency. In 1836, Bright reported that only $29 \%$ of patients with albuminous urine had healthy pleura at autopsy. ${ }^{1}$ There are several reasons why pleural disease may be common in patients with renal failure. These include congestive heart failure, an increased risk of infection, the presence of diseases associated with renal and pleural manifestations (eg, systemic lupus erythematosus), uremic pericarditis, an increased risk for certain malignancies and pulmonary embolism. Uremic pleurisy results from an unknown putative agent, and therefore uremic pleuritis is a diagnosis of exclusion.

\section{Case}

A 45-year-old Saudi male with end stage renal disease (ESRD) for more than 16 years presented with shortness of breath and right-sided pleuritic chest pain for more than 3 days and cough with whitish sputum for more than 1 month, without fever. He also reported weight loss of more than $10 \mathrm{~kg}$ in 4 months. The patient was on hemodialysis 3 times per week, had hepatitis $\mathrm{C}$ virus disease, and was recently found to have hyperthy-

Table 1: Laboratory investigations.

\begin{tabular}{ll}
\hline Serum & \\
\hline White blood cells & $14.7 \times 10^{9} / \mathrm{L}$ \\
\hline Hemoglobin & $99 \times 10^{12} / \mathrm{L}$ \\
\hline Protein & $82 \mathrm{~g} / \mathrm{L}$ \\
\hline $\begin{array}{l}\text { Lactic } \\
\text { dehydrogenase }\end{array}$ & $462 \mathrm{~g} / \mathrm{L}$ \\
\hline Urea & $19.5 \mu \mathrm{mol} / \mathrm{L}$ \\
\hline Creatinine & $587 \mathrm{mmol} / \mathrm{L}$ \\
\hline CO & $29 \mathrm{mmol} / \mathrm{L}$ \\
\hline Pleural & \\
\hline White blood cells & $673 \times 10^{6} / \mathrm{L}$ \\
\hline Red blood cells & $960 \times 10^{6} / \mathrm{L}$ \\
\hline Histocytes & $58 \%$ \\
\hline $\begin{array}{l}\text { Polymorphs } \\
\text { Lymphocytes }\end{array}$ & $20 \%$ \\
\hline Eosinophils & $12 \%$ \\
\hline $\begin{array}{l}\text { Lactic } \\
\text { dehydrogenase }\end{array}$ & $315 \mathrm{u} / \mathrm{L}$ \\
\hline Protein & $39 \mathrm{~g} / \mathrm{L}$ \\
\hline Glucose & $5.9 \mathrm{mmol} / \mathrm{L}$ \\
\hline LDH ratio & 0.68 \\
\hline & \\
\hline
\end{tabular}
roidism. He was also a smoker. The patient was taking atenolol $50 \mathrm{mg}$ orally once daily, methimazole 10 $\mathrm{mg}$ orally once daily, erythropoietin 2000 units subcutaneously per week, calcitriol $0.25 \mathrm{mg}$ orally once daily, and aluminum hydroxide 400 orally three times per day.

Initial laboratory tests are shown in Table 1. Pleural fluid cultures for bacteria and mycobacteria were negative. Chest radiography and computed topography showed bilateral pleural effusion right more than left, no pulmonary infiltrates, and no evidence of infection or infarction. The patient underwent thoroscopic pleural biopsy (Figure 1 ), which showed a layer of fibrin with underlying reactive mesothelial cells and granulation tissue, which was consistent with fibrinous pluritis. Subsequently the patient's hemodialysis regimen was intensified, with gradual improvement in symptoms and complete resolution of his pleural effusions. There was no recurrence on follow up over the following year.
From the "Department of Medicine, Section of Pulmonary Medicine E Nephrology; tDepartment of Pathology, King Faisal Specialist Hospital \& Research Center, Riyadh, Saudi Arabia

Correspondence and reprint requests:

Abdullah Al Mobeireek FRCP,

FCCP

Department of Medicine, Section of Pulmonary Medicine $\Xi^{\circ}$ Nephrology MBC 46 King Faisal Specialist Hospital E Research Center, PO Box 3354

Riyadh, 11211

Saudi Arabia

Tel: +966-1-442 7493

Fax: +966-1-4427499

mobeireek@yahoo.com

Accepted for publication May 2005

Ann Saudi Med 2006;26(2):145-146 


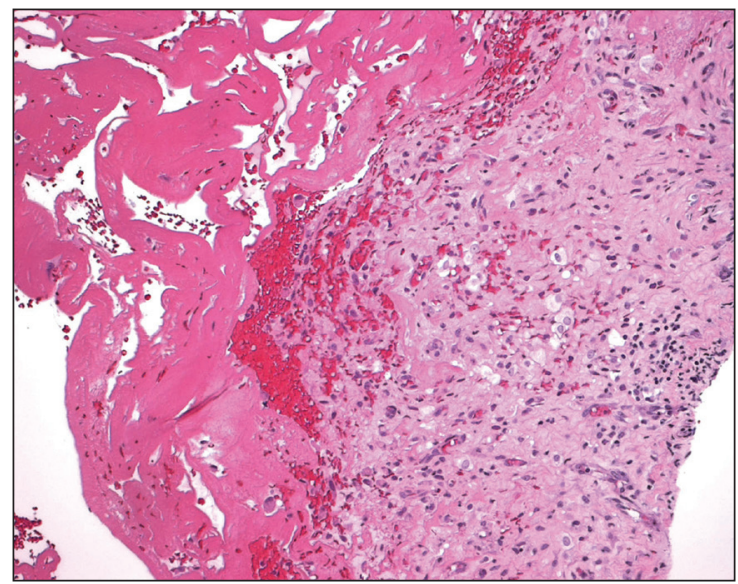

Figure 1. Thoracoscopic pleural biopsy (intermediate magnification).

\section{Discussion}

Berger and coworkers ${ }^{2}$ reported a 4\% (14 of 436) incidence of uremic pleural effusions in chronic renal failure. However, the incidence could have been underestimated because patients who had little effusion or who resolved rapidly after detection were not included. Jarratt and Sahn ${ }^{3}$ reported a 16\% (16 of 100) incidence of pleural effusion secondary to uremia.

The typical patient with uremic pleural effusion has been undergoing hemodialysis or peritoneal dialysis for one or two years, with a range of a few months, to greater than four years. Patients usually but not always have symptoms at the onset of effusion, with fever, cough, or chest pain. Dyspnea is an unusual presenting manifestation. Pericardial and pleural rub are heard in $30 \%$ to $50 \%$ of patients. The pleural rub usually persists for two or three days. Nidus et $\mathrm{al}^{4}$ found that the incidence of pleural rub is about $15 \%$ in patients with severe renal insufficiency. Only one rub was observed to at least 18 days, but others were of brief duration.

The chest radiograph typically shows a unilateral moderate-to-large pleural effusion without accompanying pulmonary infiltrates. Thoracentesis most often reveals a serosanguinous to bloody exudate. Berger et $\mathrm{al}^{2}$ found serosanguinous or hemorrhagic fluid in 10 of 14 patients. The nucleated cell count ranges from 80 to $3700 / \mathrm{mm}^{3}$ with lymphocyte predominance (averaging $70 \%$ of the cells). Only a few cases of pleural fluid eosinophilia have been reported. Pleural eosinophilia rates of $86 \%$ and $10 \%{ }^{4}$ have been noted previously. The erythrocyte count of pleural fluid was an average of $146140 / \mathrm{mm}^{3}$ (range, $\left.0.6-0.12 \times 10^{6}\right)$. Pleural fluid glucose approximates serum glucose and pleural fluid acidosis has not been observed. The creatinine concentration is high, reflecting the blood creatinine but the pleural fluid to serum fluid is less than 1.0. Berger at $\mathrm{al}^{2}$ found that all patients with uremic pleural effusion who had pleural biopsy or autopsy evidence of fibrinous pleuritis had high values for pleural protein and LDH.

Pleural effusion generally resolves with continued dialysis over several weeks, although some may later recur. Some patients will progress to fibrothorax, resulting in severe pulmonary restriction. The occurrence of fibrous pleuritis in uremic effusion may have several explanations. The pleural fluid is hemorrhagic and this in itself may produce fibrothorax..$^{5}$ Uremic toxins theoretically can be implicated since there may be exudation of protein and extensive fibrin deposition on serous membranes. Systemic heparinization during dialysis may contribute to the development of hemorrhagic effusion. ${ }^{6}$

Despite an abnormal bleeding tendency that exists in patients with renal insufficiency, decortication of the chest wall and the lung can be carried out safely with minimal bleeding and restoration of pulmonary function. ${ }^{7}$ The question of whether one can halt the progression of this process remains unanswered. One group of investigators has suggested using regional heparinization during dialysis to decrease bleeding into the pleural space. ${ }^{8}$ Installation of non-absorbable corticosteroids into the pleural space might be beneficial but has not been tried. ${ }^{9}$ Surgery seems to be the ultimate recourse if severe incarceration occurs.

\section{References}

1. Bright $R$. Tabular view of the morbid appearance in 100 cases connected with albuminous urine, with observation. Guys Hosp Rep 18 36;1:380-480

2. Berger Hw, Rammohan G, Neff MS, et al. Uremic pleural effusion: 2 study in 14 patients on chronic dialysis. Ann Intern Med 1975; 82: 362-364

3. Jarrat Mj, Sahn SA. Pleural effusion in Hospitalized patients receiving long-term hemodialysis. Chest 1995;108:470-474
4. Nidus BD, Matalon R, Cantacuzino D, et al. Uremic pleuritis - a clinic pathological entity. $N$ Engl $J$ Med 1969; 281: 255-256

5. Drapanas T, Liwin MS. Management of acutely injured patient, in Sabistan DC (ed): Davis - Christopher Text book of surgery. Philadelphia, WB Saunders Co, 1970, 369.

6. Buja LM, Friedman CA, Roberts WC. Hemorrhagic pericarditis in uremia: Clinico pathologic studies in six patients. Arch Pathol 1970; 90: 325-333 7. Gilbert L, Ribot S, Frankle H, et al. Fibrinous uremic pleuritis: a surgical entity. Chest 1975;67:53-56. 8. Galen Ma, Stenberg SM, Lowrie EG, et al: Hemorrhagic pleural effusion in patients undergoing chronic hemodialysis. Ann Intern Med 1975 82:359-361

9. Rhodelas R, Rakowski TA, Argy WP, et al. Fibrosing uremic pleuritis during hemodialysis. JAMA 1980;243:2424. 